\title{
Geophysical investigation of road pavement instability along part of Akure-Owo express way, Southwestern Nigeria
}

\author{
${ }^{*}$ Adeyemo, I.A. and Omosuyi, G.O. \\ Department of Applied Geophysics, Federal University of Technology, P.M.B. 704, \\ Akure, Nigeria. \\ *Corresponding Author: E-mail: faythyemo2003@yahoo.co.uk, \\ Phone No: +2348060042770 ,
}

\begin{abstract}
:
Integrated surface geophysical methods were used in investigating causes of pavement instability along a portion of Akure-Owo expressway, southwestern, Nigeria. The methods comprise of ground magnetic profiling, Very Low Frequency Electromagnetic (VLF-EM) profiling and geoelectric sounding. The magnetic profile shows a drop below $31500 \mathrm{nT}$ at distance $100 \mathrm{~m}$ and above $32500 \mathrm{nT}$ at distances 140 and $310 \mathrm{~m}$, these drops in value could correspond to lithological contacts or bedrock depressions. The combined plots of raw real and filtered real VLF-EM data show conductive zones at distances 70m, 230$240 \mathrm{~m}$ and $350-360 \mathrm{~m}$, which could be indicative of fractured zones or conductive clay materials. The 2-D geoelectric section shows bedrock depressions at distance $80-160 \mathrm{~m}$ (stable segment) and $240-360 \mathrm{~m}$ (unstable segment), while bedrock fractures was delineated beneath VES points $1,3,5$ and 10 , corresponding to distances $0,80 \mathrm{~m}, 160 \mathrm{~m}$ and $400 \mathrm{~m}$ respectively. The topsoil resistivity varies from 83 to $865 \mathrm{ohm}-\mathrm{m}$, while resistivity in the weathered layer materials ranges from $182-1139 \mathrm{ohm}-\mathrm{m}$ along the stable segment and $27-2620 \mathrm{hm}-\mathrm{m}$ along the unstable segment. The low resistivity values observed beneath the unstable segment are typical of expansive clay. Thus the instability of the road pavement along the studied portion of the road is probably precipitated by the presence of near surface bedrock depressions, occupied by low resistivity weathered materials, typical of expansive clay and sandy clay, adjudged unsuitable construction materials.
\end{abstract}

Keywords: Pavement instability, expansive clay, weathered layer and bedrock depression

\section{INTRODUCTION:}

The Akure-Owo express way is a major road connecting the western and northern parts of the country and thus a very busy federal road. Several repair works have been done on different portions of this road over the years but the unstable nature of these portions still persists. A lot of reasons have been suggested for the incessant failure of roads in Nigeria: such as presence of expansive clays such as montmorillonite, chlorite, halloysite etc (Mesida, 1986 and 1987), heterogeneity of the subgrade materials (Adeleye, 2005 and Mesida, 1987), presence of undetected linear features, such as joints, fractures and rock boundaries (Momoh et al., 2008), poor construction practice and the use of substandard materials for road construction, among others. In addition to the aforementioned factors, bedrock relief (or depression) can also precipitate instability in road pavements. This work presents a typical instance where bedrock relief, presence of expansive soils and poor road construction practice had contributed in precipitating road instability.

Location and Geologic Setting: The study area is a $400 \mathrm{~m}$-long segment along Akure-Owo express way, in Ondo State, southwestern Nigeria (Fig. 1and 2). It lies between Universal Mercator coordinates $31 \mathrm{~N} 0741143$ and 31 N0741493 (Easting); and UTM0805548 and UTM0805638 (Northing). The area falls within tropical rainforest belt where there exist two distinct seasons; dry and wet. This stretch of road is underlain by Precambrian Basement Complex rocks of southwestern Nigeria (Rahaman, 1976). The local rock unit in the area is Porphyritic Granite, characterized by large crystal of rock forming minerals, such as quartz, feldspar and biotite. 


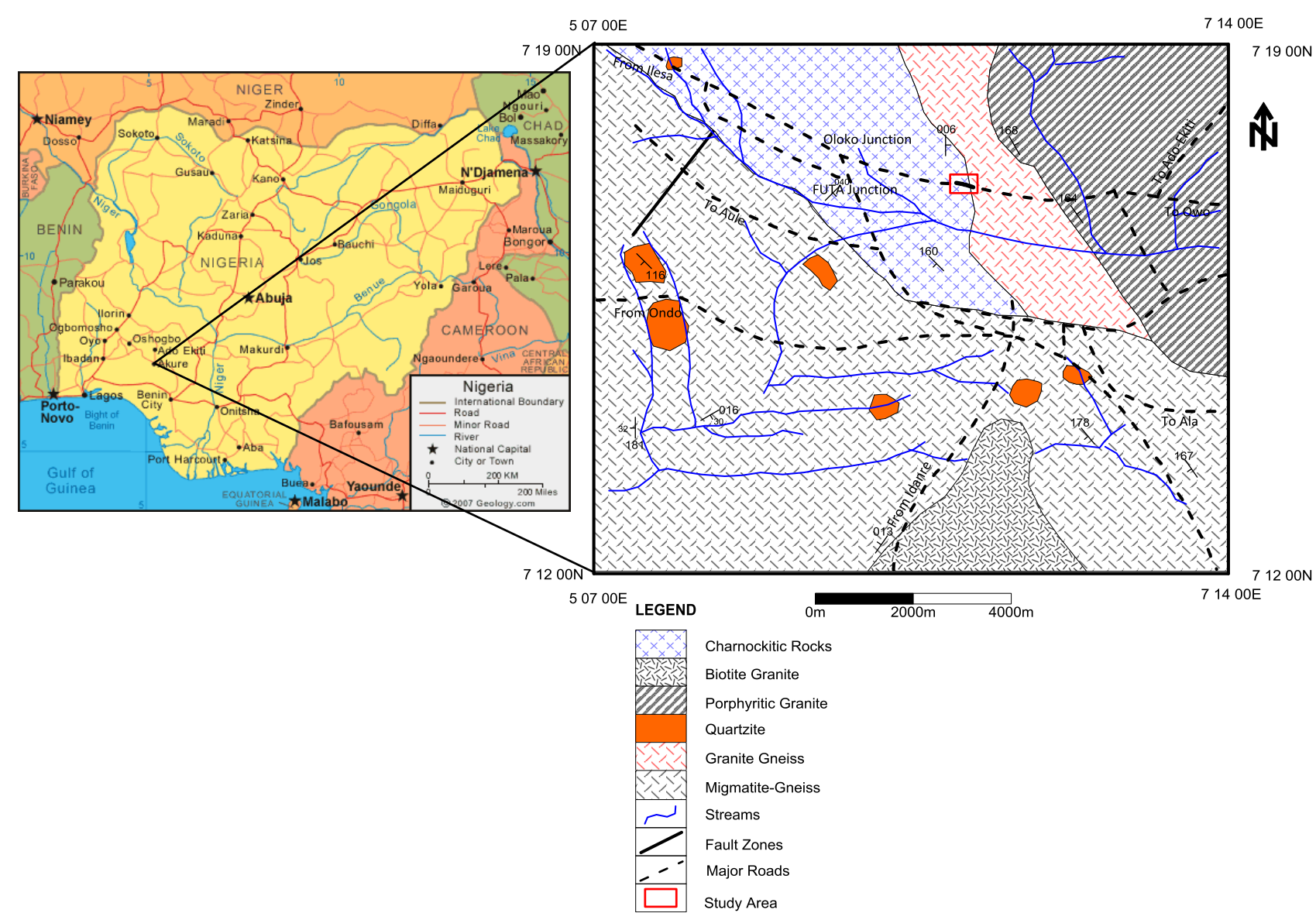

Fig. 1: Simplified geological map of Akure, showing the study area (Modified after Owoyemi, 1996), Left: Administrative map of Nigeria.

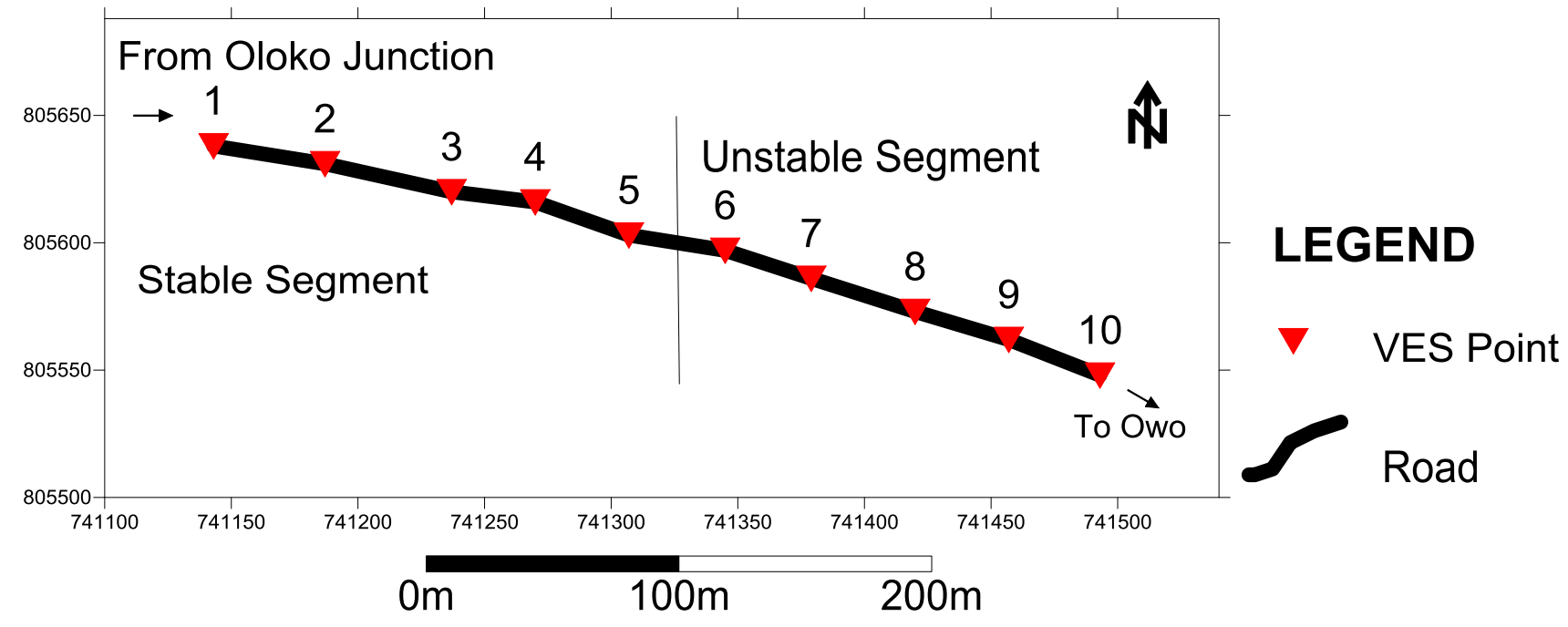

Fig. 2: Location map of the study area, showing the stable and unstable road segments. 


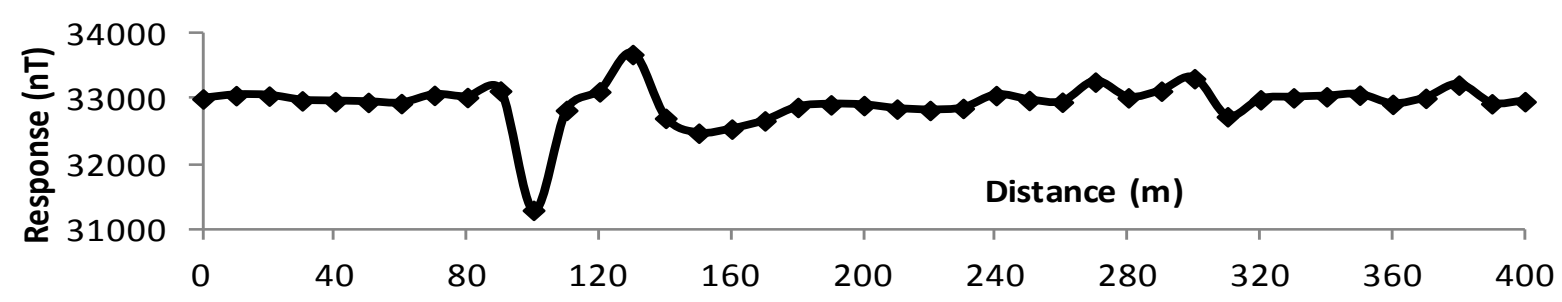

Fig. 3: Magnetic Profile of the studied portion of Akure-Owo road, Akure.

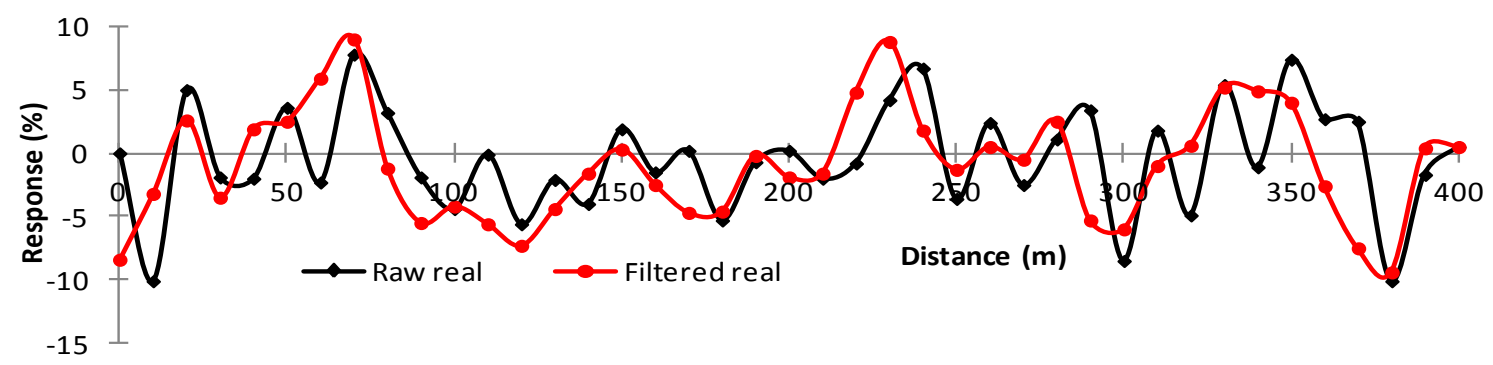

Karous-Hjelt filtering
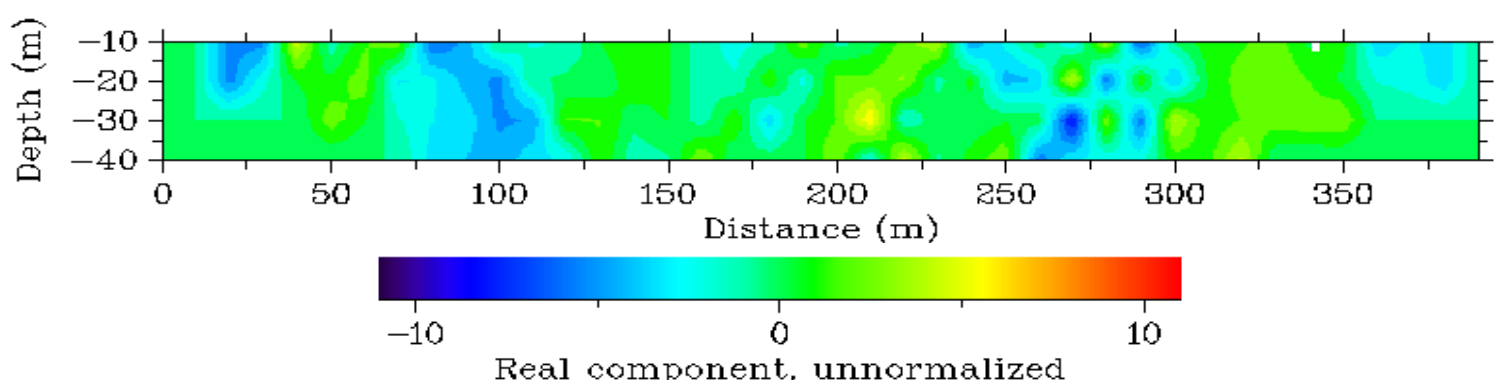

Fig. 4: VLF-EM Profiles and Pseudosection of a Portion of Akure-Owo Road, Akure.
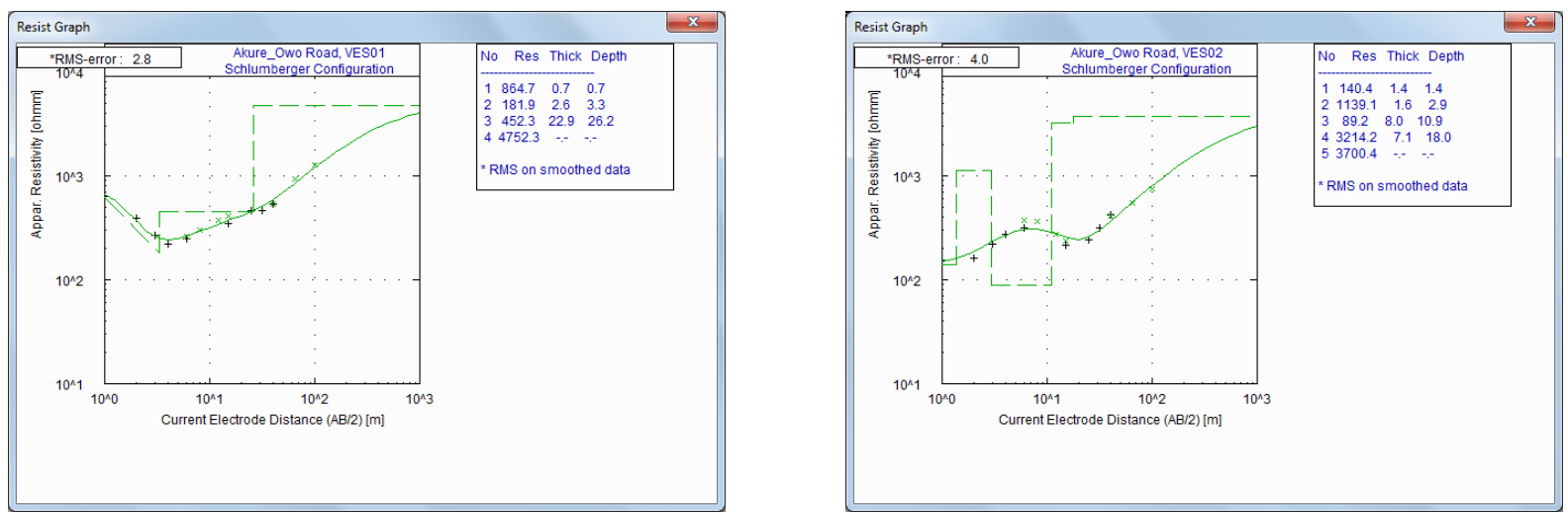
Am. J. Sci. Ind. Res., 2012, 3(4): 191-197
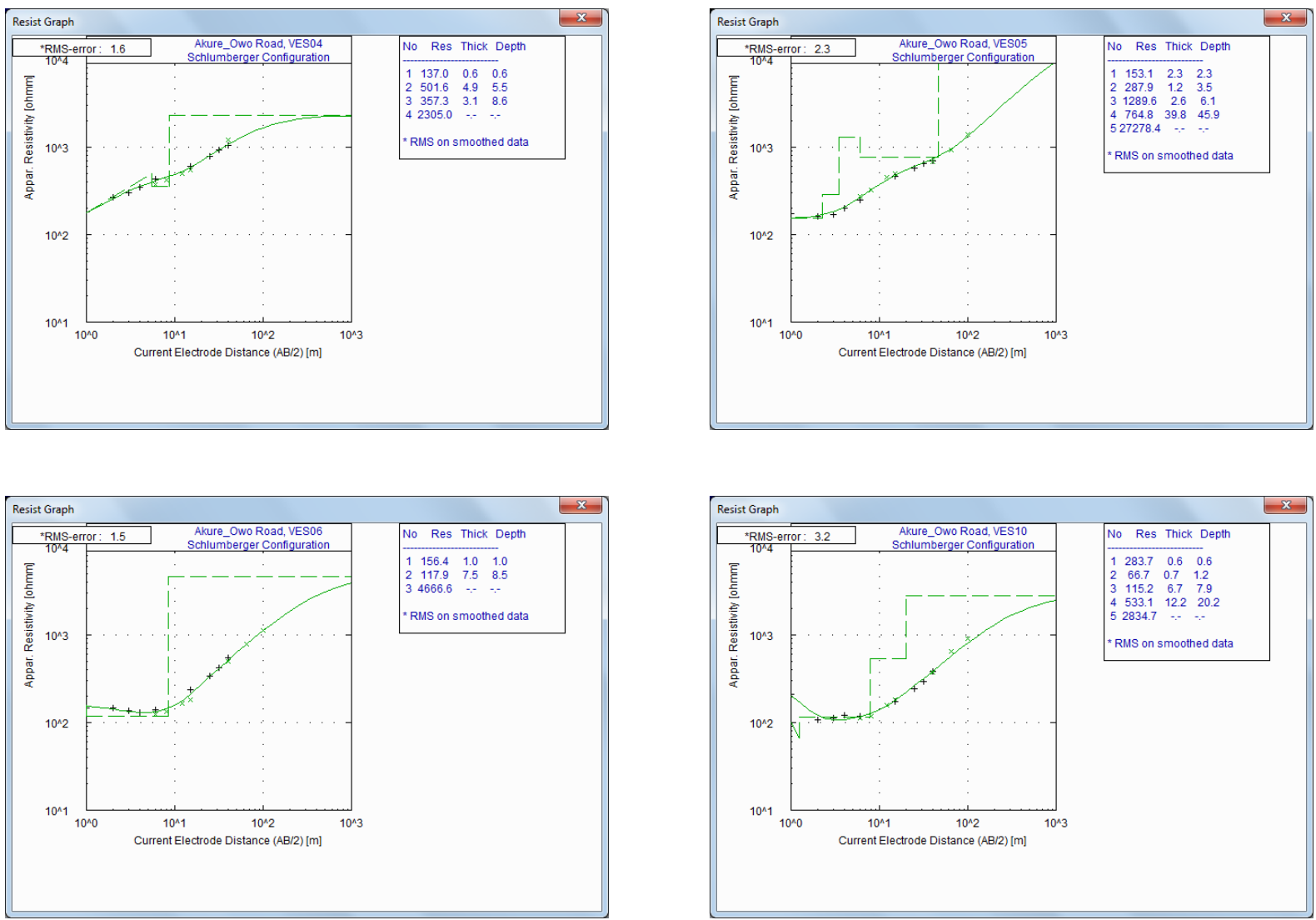

Fig.5: Typical VES curves from the study area

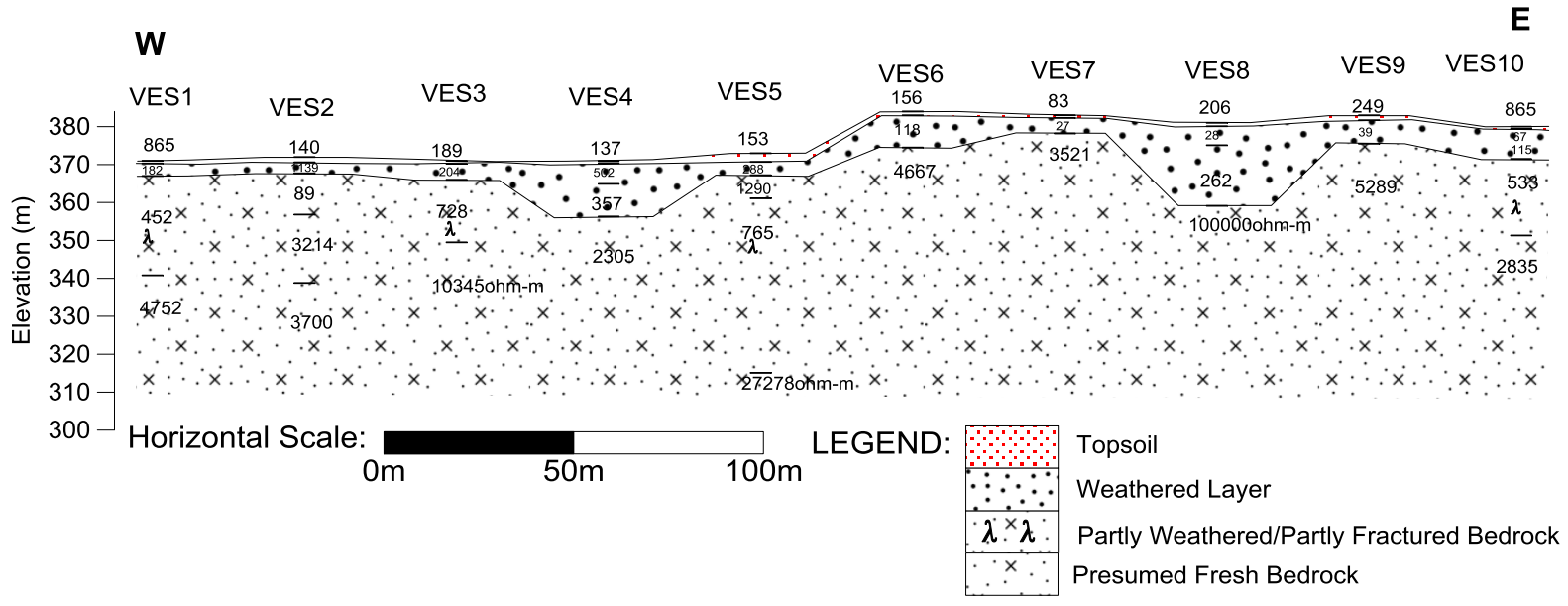

Fig. 6: Geoelectric section of the studied section of Akure-Owo road, Akure. 


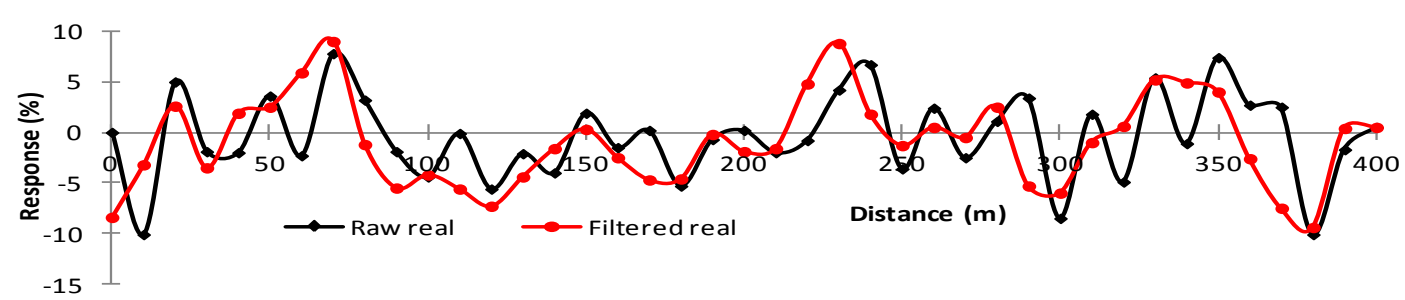

Karous-Hjelt filtering 'Akure_owo Road Profile'

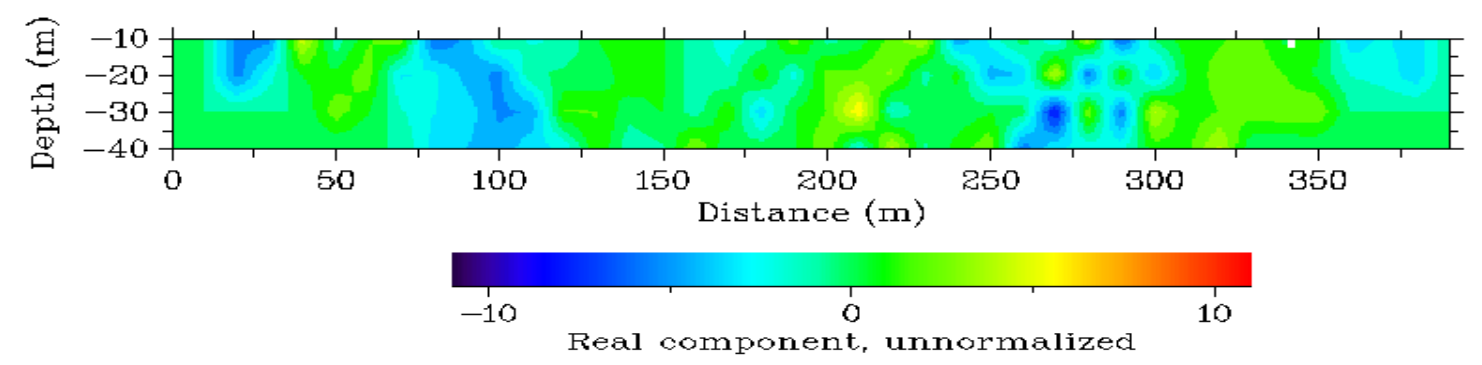

(a)

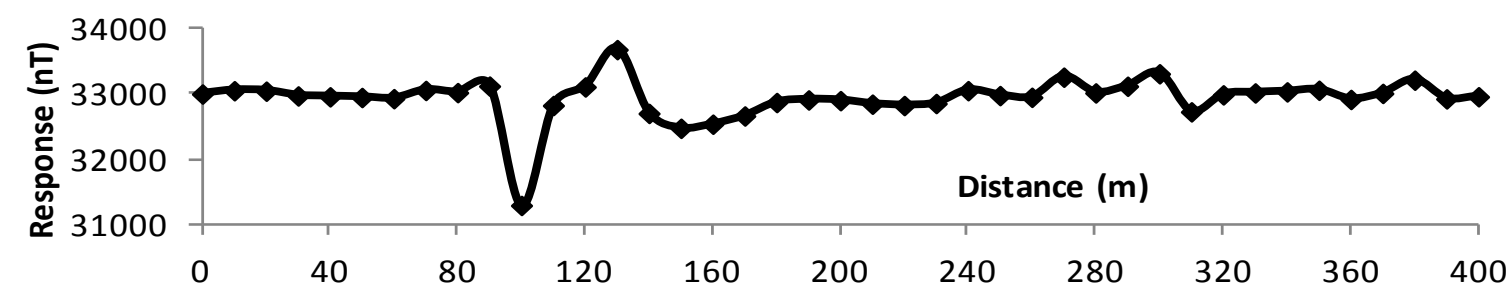

(b)

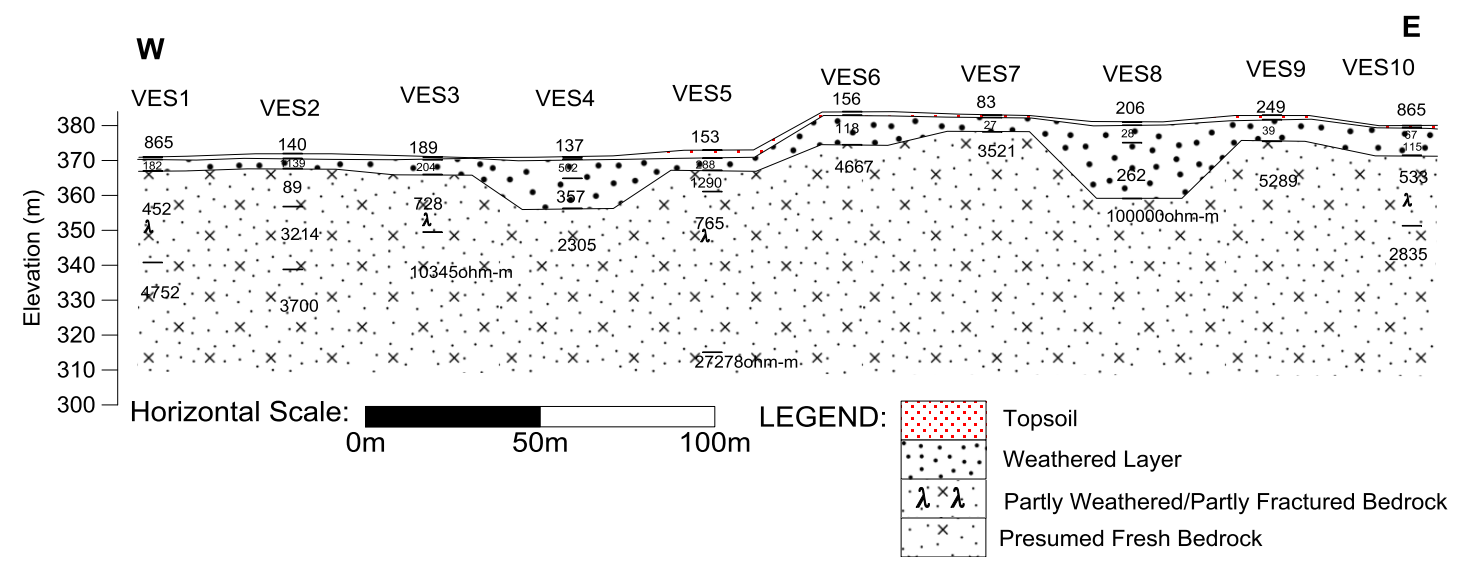

(c)

Fig. 7a-c: Correlation of VLF-EM profile, magnetic profile and geoelectric section. 


\section{MATERIALS AND METHODS:}

Three surface deployed geophysical methods comprising ground magnetic profiling, very low frequency electromagnetic (VLF-EM) profiling and electrical resistivity methods were integrated in this study.

The ground magnetic profiling survey was carried out along a $400 \mathrm{~m}$ long segment of Akure-Owo expressway consisting of both failed and stable portions of the road. A GEM Proton Magnetometer was used to collect ground magnetic survey data at $10 \mathrm{~m}$ intervals. The magnetic profiling data was corrected for drift error and the drift corrected data were plotted against their station positions.

ABEM Wadi portable VLF-EM surveying equipment was used to acquire VLF-EM data. This equipment was capable of acquiring both in-phase and out-ofphase components data. The raw real data were filtered using Karous-Hjelt filter factor (Karous and Hjelt, 1983 and Pirttijärvi, 2004):

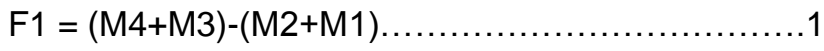

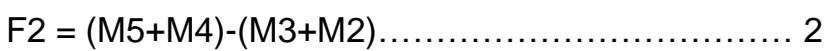

Where, $F 1$ and $F 2$ are $1^{\text {st }}$ and $2^{\text {nd }}$ filter factors respectively, and $\mathrm{M} 1, \mathrm{M} 2, \mathrm{M} 3, \mathrm{M} 4$ and $\mathrm{M} 5$ are measurements taken at station 1,2, 3, 4 and 5 respectively, and $\mathrm{F} 1$ and $\mathrm{F} 2$ are plotted at the middle of stations 2 and 3 , and middle of stations 3 and 4 respectively and so on (Reynolds, 1977). The results are presented as a plot of both raw and filtered real values against station positions and pseudosection.

PASI 16GL resistivity meter was used in acquiring vertical electrical sounding (VES) data. Schlumberger electrode array (Patra and Nath, 1998) was adopted for the depth sounding with maximum current electrode separation (AB) of $100 \mathrm{~m}$. A total of $10 \mathrm{VES}$ points were occupied. The VES data were interpreted based on the approach of Keller and Frishchnecht (1966) and Koefoed (1979). The manually derived geoelectric parameters were further refined using a forward modeling software, RESIST version 1.0 (Vander Velpen, 1986).

\section{RESULTS AND DISCUSSION:}

The ground magnetic profile (Fig. 3) shows a significant drop below $31500 \mathrm{nT}$ at distance $100 \mathrm{~m}$ and minor drops at distances 140 and $310 \mathrm{~m}$ (above $32500 \mathrm{nT}$ ). These drops in value could correspond to lithological contact or bedrock depression. The VLFEM profile (Fig. 4) combined plots of raw real and filtered real values against station positions on the same plot, since this has a lot of merit; the filtered real plot is better used to identify real anomalies, while the raw real plot is better used to identify anomaly positions (Reynolds, 1997). The combined plots show conductive zones at distance $70 \mathrm{~m}, 230$ $240 \mathrm{~m}$ and $350-360 \mathrm{~m}$, which could be indicative of fractured zones or conductive clay materials (Karous and Hjelt, 1983). The depth sounding data gives various curve types (Fig. 5) ranging from $A A, H, H A$, $\mathrm{HAA}, \mathrm{KH}, \mathrm{KHA}$ to $\mathrm{KKH}$. The 2 dimensional geoelectric section (Fig. 6) shows bedrock depressions at distance $80-160 \mathrm{~m}$ (stable segment) and $240-360 \mathrm{~m}$ (unstable segment), while bedrock fractures was delineated beneath VES points 1, 3, 5 and 10, corresponding to distances $0,80,160$ and $400 \mathrm{~m}$. The topsoil resistivity varies from 83 to $8650 h m-m$, while resistivity in the weathered layer material ranges from $182-1139 \mathrm{ohm}-\mathrm{m}$ along the stable segment and $27-262 \mathrm{ohm}-\mathrm{m}$ along the unstable segment. The low resistivity values observed beneath the unstable segment are typical of expansive clay. It is also observed that drainage were not provided for the run-off water flowing from road cuts on both sides of the failed segment, such that pool of water always accumulate at the road shoulders. A combined view of the results (Fig. 7) showed that the instability of the road pavement along the studied portion of the road is probably precipitated by the presence of bedrock depression occupied by low resistive weathered layer materials, typical of expansive clay beneath this section and poor construction practice.

Conclusion: Surface geophysical investigation methods involving, Ground magnetic profiling, VLFEM profiling and electrical resistivity method had been used essentially in this study to delineate possible causes of road pavement instability along a segment of Akure-Owo expressway, Akure, Nigeria. The results show that bedrock depressions, clayey composition of the overlying weathered materials and poor construction practice were responsible for the precipitation of pavement instability along the studied segment of this road.

Acknowledgment: The authors express gratitude to the following staff and students of Applied Geophysics Department, Federal University of Technology, Akure for assisting during data acquisition of this work: Mr. Ajayi-Gidi, Adesun, J., Jonibola, O. and Amosun, J. We are also grateful to the Department of Applied Geophysics, Federal University of Technology, and Akure for allowing the use of departmental equipment. 


\section{REFERENCES:}

Adeleye, A.O. (2005). Geotechnical Investigation of Subgrade Soil along Sections of Ibadan-lle Highway, Unpublished M.Sc. Project, Obafemi Awolowo University, Ile-Ife, , 181pp.

Karous, M. and Hjelt, S.E. (1983). Linear filtering of VLF dip-angle measurements. Geophysical Prospecting 31, 782-794.

Keller, G.V. and Frishchnecht, F.C. (1966). Electrical Methods in Geophysical Prospecting. Pergamon Press, New York, pp. 96.

Koefoed, O. (1979). Geosounding Principles 1. Resistivity Measurements. Elsevier Scientific Publishing, Amsterdam, Netherlands, pp. 275.

Mesida, E.A. (1986). Some Geotechnical Properties of Residual Mica Schist Derived Subgrade and Fill Materials in the Ilesha Area, Nigeria, No. 33, pp. 1417.

Mesida, E.A. (1987). The Relationship Between the Geology and the Lateritic Engineering Soils in the Northern Environs of Akure, Nigeria, Bulletin of the international Association of Engineering Geology, No. 35, pp. 65-69.

Momoh, L. O, Akintorinwa, O and Olorunfemi, M.O. (2008). Geophysical Investigation of Highway Failure - A Case
Study from the Basement Complex Terrain of Southwestern Nigeria, Journal of applied Sciences Research, Vol. 4, No. 6, pp. 637-648,

Owoyemi, F.B. (1996). A Geological-Geophysical Investigation of Rain-Induced Erosional Features in Akure Metropolis. Unpublished. M.Tech Thesis, Federal University of Technology: Akure, Nigeria, pp. 11-18.

Patra, H.P. and Nath, S.K. (1998). Schlumberger Geoelectric Sounding in Ground Water. Principles, Interpretation and Application. A. A. Balkema Publishers, USA. pp. 153.

Pirttijärvi, M. (2004). Karous-Hjelt and Fraser Filtering of VLF Measurements. Manual of the KHFFILT Programme.

Rahaman, M.A. (1989). Review of the basements geology of southwestern Nigeria. In Kogbe, C.A., (ed.) Geology of Nigeria, pp. 39-56.

Reynolds, J.M. (1977). An Introduction to Applied and Environmental Geophysics. Published by John Wiley and Sons, Chichester, England, 800pp.

Vander, V. (1988). "Resist Version 1.0". M. Sc. Research Project. ITC, Delft, Netherlands. 